\title{
IZOTOPOVÝ ZÁZNAM PRVNÍCH SPODNÍCH MOLÁRŮ DOMÁCÍHO SKOTU Z RANĚ STŘEDOVĚKÝCH LOKALIT POHANSKO-JIŽNÍ PŘEDHRADÍ A KOSTICE-ZADNÍ HRÚD (ČESKÁ REPUBLIKA)
}

\author{
Isotope record of the first lower molars of domestic cattle from the early medieval \\ Pohansko-Southern bailey and Kostice-"Zadní hrúd" localities (Czech Republic) \\ Martin Ivanov ${ }^{1} \llbracket$, Hana Nohálová', Miriam Nývltová Fišáková2, Petr Dresler, \\ Gabriela Dreslerová ${ }^{3}$ \\ 'Ústav geologických věd, PřF MU, Kotláŕská 2, 61137 Brno \\ ${ }^{2}$ Laboratoř paleontologie a zooarcheologie, Archeologický ústav AVČR, Brno, v.v.i., Čechyňská 363/19, 60200 Brno \\ ${ }^{3}$ Ústav Archeologie a Muzeologie, FF MU, Arna Nováka 1/1, 60200 Brno
}

Key words: Isotope analysis $\left(\delta^{13} \mathrm{C}, \delta^{15} \mathrm{~N}\right)$, dentition, breeding, Pohansko agglomeration, Czech Republic

\begin{abstract}
In this essay, we focused on the evaluation of isotope analyses $\left(\delta^{13} C_{\text {coll }}\right.$ and $\delta^{15} N_{\text {coll }}$ ) of the first lower molars ( $m 1$ ) of domestic cattle (Bos taurus) from two early medieval Pohansko-Southern bailey (Pohansko-JP) and Kostice-"Zadní hrúd" (Kostice-ZH) sites. The aim of the study is the evidence of the breast-feeding effect of calves and subsequent weaning on the dentine average isotope composition. Results from both sites are compared with the data obtained from recent experimental cattle breeding. Possible differences in the cattle breeding between both studied localities are evaluated. The first lower molars of the domestic cattle $(n=15)$ were selected for analyses from both sites supplemented by a sample of the compact bone of the shinbone of an adult individual from the Pohansko$J P$ site. The determination of the ontogenetic age of the analyzed individuals is based on the dentition development stage. For the purpose of isotope analyzes $\left(\delta^{13} \mathrm{C}_{\text {coll }}\right.$ and $\left.\delta^{15} \mathrm{~N}_{\text {coll }}\right)$, dentine collagen was extracted from all tooth crowns. The $\delta^{13} \mathrm{C}_{\text {coll }}$ dentine values of the $m 1$ of cattle from the Pohansko-JP ranged from $-17.75 \%$ to $-21.8 \%$ o $(n=11)$ with mean value of $-19.81 \pm 1.03 \%$. $\delta^{15} N_{\text {coll }}$ values for dentine of all $m 1$ samples from Pohansko-JP range from $6.2 \%$ to $11.87 \%$ with mean value of $8.29 \pm 1.71 \%$ o $(n=11)$. The highest $\delta^{15} N_{\text {coll }}$ values were observed primarily in samples of juvenile individuals, with the exception of one adult specimen (10.90\%). $\delta^{13} C_{\text {coll }}$ values in $m 1$ of adult individuals from the Kostice- $Z H$ site range from $-19.30 \%$ to $-20.91 \%$ o $\left.n=4\right)$. The mean value -19.83 $\pm 1.01 \%$ is lower if compared to results from recent experimental breedings. The volume of ${ }^{15} \mathrm{~N}$ isotope is significantly lower contrary to those in Pohansko-JP and aforementioned experimental study. It can be assumed that the diet of the cattle in both studied sites was primarily based on C3 plants; however, we cannot exclude a small admixture of C4 plants (millet) in the diet of some observed individuals. The cattle from the Pohansko-JP could be driven to graze from the open meadows up to the ecotones in the vicinity of the forest which is partly supported by the palaeobotanic record. In Kostice-ZH site, the grazing in open meadows was most prevalent. The volume of ${ }^{15} \mathrm{~N}$ from the Pohansko-JP site shows that in most cases, calves were not prematurely weaned. In samples from Kostice- $\mathrm{ZH}$, the ${ }^{15} \mathrm{~N}$ content in adult individuals was significantly lower contrary to values from Pohansko-JP. A present stage of the knowledge indicates that the cattle (i.e., including mother cows) was probably fed plants characterized by low $\delta^{15} \mathrm{~N}$ values; however, a premature weaning to increase the milk production cannot be excluded.
\end{abstract}

Úvod

V současnosti existuje řada prací zaměřených na výzkum složení potravy na základě informací z izotopového záznamu kostního kolagenu a hydroxyapatitu (např. Ambrose 1990; Reitsema et al. 2010; Bocherens, Drucker 2003; Makarewicz, Sealy 2015). U zubů je nejčastěji studována zubní sklovina, z jejíhož izotopového složení je možné vyvodit environmentální i klimatické závěry (např. Fricke, O’Neil 1996; Fricke et al. 1998; Balasse et al. 2005), některé studie sledují izotopové složení kolagenu a apatitu ze zubního dentinu (např. Koch et al. 1989, 1995; Bocherens et al. 1994, 1995; Richards et al. 2002; Fuller et al. 2003). Vychází se ze skutečnosti, že ukončení vývoje zubu je spojeno s ukončením tvorby zubního dentinu, jenž posléze neprodělává remodelaci. Dentin si tak na rozdíl od trvale remodelované kostní tkáně zachovává izotopové složení odrážející pouze období vývoje konkrétního

$\square$ mivanov@sci.muni.cz

DOI: https://doi.org/10.5817/GVMS2018-1-2-07 zubu. Bocherens et al. (1994, 1995, 1997) výzkumem izotopového složení brachyodontních zubů savců ukázali na rozdíly v obsahu ${ }^{15} \mathrm{~N}$ mezi kolagenem zubního dentinu a kostním kolagenem. Navýšení hodnot $\delta^{15} \mathrm{~N}_{\text {coll }} \mathrm{v}$ dentinu oproti kostní tkáni dospělých jedinců bylo vysvětleno skutečností, že dentin, vyvíjející se převážně v juvenilním až subadultním období života jedince, zachycuje zvýšený izotopový signál dusíku z období kojení. Naproti tomu u kontinuálně se vyvíjející kosti tento signál po odstavení mlád’at postupně zaniká a výsledné izotopové složení tak odráží přechod na jinou stravu. Hlavní výhoda studia zubů spočívá v tom, že jejich vývoj můžeme poměrně přesně časově vymezit (Brown et al. 1960; Balasse et al. 2001).

Ačkoliv je známo, že dentin recentních savců zachycuje podrobný izotopový záznam (Koch et al. 1989; Hobson, Sease 1998), aplikace sekvenčních studií na fosilní materiál terestrických savců je omezená (Balasse et al. 2001). První detailní sekvenční studie vzorků zubního dentinu byly provedeny na experimentálních vzorcích hypsodontního chrupu recentního domácího skotu (Bos taurus) z farmy ve Vendée (Francie). Studovány byly 


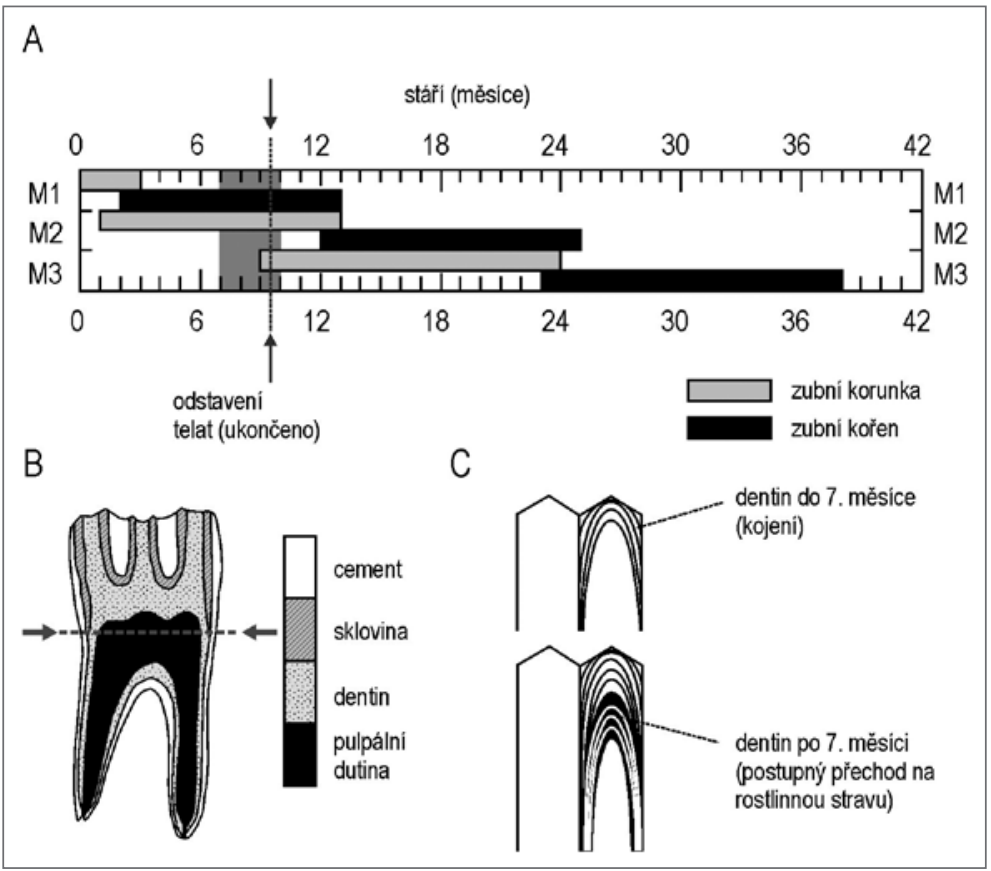

Obr. 1: A - chronologie růstu spodních molárů (m1 až m3) u tura domácího. Svislý tmavě šedý pruh - obvyklá doba odstávky telat u recentních chovů (Balasse et al. 2001, upraveno); B - podélný řez spodním molárem (m1 nebo m2) tura domácího, šipkami naznačeno místo př́íčného řezu na bázi korunky zubu (Beasley et al. 1993, upraveno); C - sekvence růstu zubního dentinu u moláru skotu (Balasse et al. 2001, upraveno).

Fig. 1: A - Chronology of development of mandibular molars ( $\mathrm{m} 1$ to $\mathrm{m} 3$ ) in cattle. The vertical dark-greyish band represents usual time of calf weaning in recent breeding (Balasse et al. 2001, modified); B - longitudinal section through the lower molar ( $\mathrm{m} 1$ or $\mathrm{m} 2)$ in cattle, arrows indicate position of the cross-section at the base of the tooth crown (Beasley et al. 1993, modified); C - chronology of the tooth dentine growth in cattle molar (Balasse et al. 2001, modified).

změny ve složení dentinu spodních stoliček (m1, m2, m3) u pěti jedinců s kontrolovaným příjmem stravy v podobě C4 a C3 rostlin (Balasse et al. 2001). Ze známé doby vývoje $\mathrm{m} 1, \mathrm{~m} 2$ a m3 (Brown et al. 1960) se relativními změnami izotopového složení $\left(\delta^{13} \mathrm{C}\right.$ a $\left.\delta^{15} \mathrm{~N}\right)$ v průběhu ontogeneze prokázalo, že období kojení telat je spojeno s nejnižšími obsahy izotopu ${ }^{13} \mathrm{C}$ a zároveň s nejvyššími obsahy izotopu ${ }^{15} \mathrm{~N}$. S přechodem na stravu tvořenou $\mathrm{C} 4 / \mathrm{C} 3$ rostlinami (v experimentální studii mezi 7. a 10. měsícem) se hodnoty $\delta^{13} \mathrm{C}$ progresivně zvyšují a zároveň dochází k progresivnímu snižování hodnot $\delta^{15} \mathrm{~N}$ (Balasse et al. 2001). Sekvenční řezy plně vyvinutých druhých spodních molárů (m2) zachycují izotopový záznam od prvního měsíce po narození až po dobu asi 2 let věku jedince, kdy izotopový záznam odráží konzumaci výhradně rostlinné potravy. Dentin prvních spodních molárů (m1) naproti tomu lépe zachycuje změny izotopového složení, především $\delta^{15} \mathrm{~N}$, v časovém rozpětí od narození až po období odstavení telat, kdy postupně dochází $\mathrm{k}$ úplnému přechodu na rostlinnou stravu (Balasse et al. 2001).

Posloupnost růstu $\mathrm{m} 1 \mathrm{u}$ recentního domácího skotu (Balasse et al. 2001) ukazuje, že m1 má růst korunky ukončen v prvních 3 měsících života jedince (obr. 1A). Od 3. do 13. měsíce roste kořenová část zubu a v pulpální dutině po 7. měsíci zesiluje signál z ukládání dentinu odrážející přechod na rostlinnou stravu. Ve 13. měsíci je vývoj m1 ukončen. Vrcholová část zubní korunky obsahuje dentin, který se vytváří v prvních měsících života, kdy je jedinec živen výlučně mateřským mlékem. Střední část zubní korunky plně vyvinuté $\mathrm{m} 1$ zachycuje období kojení a přechodu na rostlinnou stravu (obr. 1B, C). Dentin ze spodní části zubní korunky $\mathrm{m} 1 \mathrm{a} \mathrm{z}$ kořenové části zubu zachycuje izotopový signál z doby přechodu na rostlinnou stravu. $\mathrm{V}$ izotopovém složení dentinu se kompletní přechod na rostlinnou stravu projevuje se zpožděním a $\mathrm{z}$ důvodu příliš časného ukončení vývoje m1 (13. měsíc) není analýza dentinu $\mathrm{z} \mathrm{m} 1$ vhodná $\mathrm{k}$ analýze stravy po úplném odstavení mlád’at. Z izotopových dat publikovaných Balasse et al. (2001) vyplývá, že průměrné složení dentinu $\mathrm{m} 1 \mathrm{a} \mathrm{m} 2$ je významně ovlivněno kojením, lze tedy předpokládat, že se kojení telat odrazí i v průměrném izotopovém složení dentinu m1 na námi studovaných vzorcích.

Předložená studie je zaměřena na výzkum složení stravy domácího skotu (Bos taurus) z lokalit Pohansko-Jižní předhradí a Kostice-Zadní hrúd v prvním roce života. Cílem studie je objasnit: 1 . jak se odráží kojení mlád’at v izotopovém záznamu m1 u jedinců různého stáří a porovnání $s$ výsledky referenční studie Balasse et al. (2001); 2. interpretace výsledků v kontextu posouzení změn izotopového složení $\left(\delta^{13} \mathrm{C}\right.$, $\left.\delta^{15} \mathrm{~N}\right) \mathrm{v}$ důsledku změny trofické úrovně spojené s odstavením telat; 3 . posoudit rozdíly ve způsobu chovu skotu mezi oběma lokalitami.

\section{Studované lokality}

Pohansko-Jižní předhradí (dále Pohansko-JP; obr. 2a, b): Aglomerace na Pohansku (ca 1,5 km j. od Břeclavi) zaujímala v 9 . století rozlohu přibližně 55 ha a rozdělena byla na opevněnou centrální část a dvě předhradí: severovýchodní a jižní. Jižní předhradí (9. stol. n. 1.) leží j. až jz. od centra hradiska. Má nepravidelně oválný obrys o rozměrech cca $700 \times 350 \mathrm{~m}$, orientovaný ve směru ZSZVJV (Přichystalová 2011). Archeologickým výzkumem pod vedením Ústavu archeologie a muzeologie FF MU v Brně bylo odkryto bylo více než 1400 sídelních objektů a více než tisíc hrobů (Dresler, úst. sdělení), ve kterých se objevily zbraně a ostruhy. Jednoznačně to dokládá přítomnost vojenské posádky (Vignatiová 1992; Macháček 2007).

Kostice-„Zadní hrúd“ (dále Kostice-ZH): Lokalita je vzdálena $1,5 \mathrm{~km}$ sv. od středu centra na Pohansku. Situována je při okraji nivy řeky Dyje na vrcholku nevýrazné písečné duny pokryté částečně degradovanou fluvickou černicí. Výzkum z let 2009-2011 prokázal, že nejvíce nálezů spadá do 6. až 13. století s vrcholem mezi 2. pol. 10. století až koncem 11. století. V 9. stol. mohla lokalita představovat subsistenční základnu rozlehlé velkomoravské aglomerace na Pohansku a po svém zániku 
se transformovala $\mathrm{v}$ řemeslně-agrární a obchodní centrum druhého řádu. Sídliště v Kosticích zřejmě zčásti přebíralo ve 2. pol. 10. stol. funkci velkomoravského Pohanska, která vyplývala z jeho strategické polohy při soutoku Moravy s Dyjí (Macháček et al. 2013).

$\mathrm{Na}$ Pohansku-JP a v Kosticích-ZH se chovaly především domestikované formy zvířat (tur, ovce/koza, prase, kůň, pes, kočka, kur, husa) s výraznou převahou jatečních zvířat, tj. tura, ovce/kozy a prasete (Dresle-

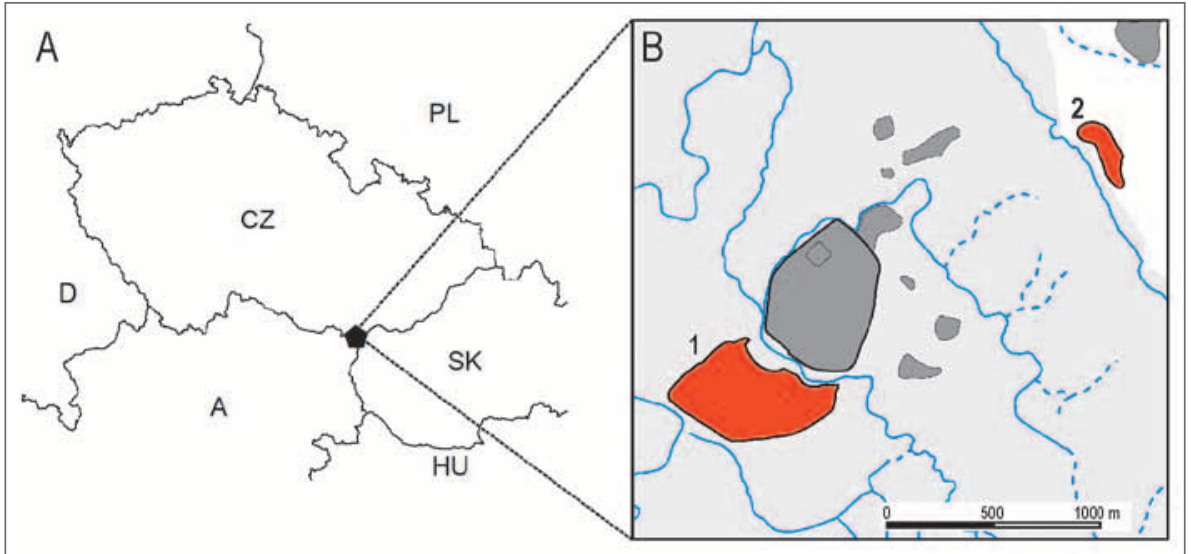

Obr. 2: Poloha lokalit Pohansko a Kostice-,ZZadní hrúd” (A, B). Na obr. 2B je červeně zachycena pozice poloh Pohansko-Jižní předhradí (1) a Kostice-„Zadní hrúd” (2).

Fig. 2: Geographic location of Pohansko and Kostice-,ZZadní hrúd“ (A, B). Fig. 2B shows positions (red colour) of Pohansko-Southern bailey (1) and Kostice-,„Zadní hrúd“ (2) excavations. rová et al. 2013).

\section{Materiál a metody}

Do analýzy bylo z lokality Pohansko-JP zahrnuto 11 vzorků $m 1$ různých jedinců tura domácího a vzorek kompakty holenní kosti (tibia) jednoho dospělého jedince. Zlokality Kostice-ZH byly analyzovány 4 vzorky $\mathrm{m} 1$ tura domácího. Stáří analyzovaných jedinců bylo zjištěno ze známé sekvence vývoje zubních korunek a kořenů $\mathrm{m} 1$ až m3 (obr. 1A; Brown et al. 1960; Balasse et al. 2001) a podle stupně abraze zubů. Vzorky $\mathrm{m} 1 \mathrm{z}$ Pohanska-JP náležely 7 adultním jedincům s ukončeným vývojem m1 (prořezává se v 5. až 6. měsíci po narození) a m2 (prořezává se v 15. až 18. měsíci po narození) a jasně prořezaným třetím spodním molárem (m3; prořezává se ve 24 . až 28. měsíci po narození). Tito jedinci byli poraženi ve stáří nejméně 24 měsíců. Čtyři jedinci tohoto setu (P-133974, P-132547, P-133132 a P-127414) vykazovali jasné známky abraze zubní korunky, jednalo se tedy nejspíše o starší jedince. Dva vzorky (P-133350, P-133585) náležely patrně mladým adultním jedincům se zuby, jež nenesly žádné známky abraze. U vzorku P-133350 není m3 zcela prořezaná, jedná se tedy patrně o mladého jedince 1-2 roky starého. Dva vzorky $\mathrm{m} 1$ (P-205665, JZP-139a) náleží velmi mladým jedincům, což dokládá neukončený vývoj m2 (vyvinuta pouze korunka) a absence prořezané $m 3$. U vzorku P-205665 je v čelisti patrný čtvrtý mléčný premolár (dp4). Stáří tohoto jedince lze odhadnout na dobu do 6 měsíců. Na lokalitě Kostice-ZH byli analyzováni 4 jedinci (KZH-1874, KZH-H03, KZH-30, KZH-179), s výjimkou vzorku KZH-30, který náležel mladému jedinci nejvýše 12 měsíců starému (m2 nemá vyvinuty kořeny), se jednalo o dospělé jedince s ukončeným vývojem $\mathrm{m} 1$ a $\mathrm{m} 2$.

Př́íprava vzorků na analýzu stabilních izotopů $\delta^{13} \mathrm{C}, \boldsymbol{\delta}^{15} \mathrm{~N}$ : U všech zubů byl analyzován kolagen extrahovaný z dentinu zubní korunky (obr. 1B). Zuby byly po extrakci z čelistí nejdříve pečlivě očištěny proudem tekoucí vody a poté vloženy do vodní lázně s destilovanou vodou, ve které byly vyčištěny od zbytku povrchových nečistot pomocí ultrazvukové čističky (Powersonic UCC1). Následovalo ruční oddělení dentinu od skloviny a poté rozdrcení dentinu na drobné úlomky. Úlomky dentinu byly chemicky ošetřeny $1 \mathrm{~N}$ kyselinou octovou $\mathrm{v}$ podmínkách periodického vakuování za účelem odstranění povrchově absorbovaných a sekundárně vysrážených karbonátů. Chemicky vyčištěný vzorek byl následně ve vakuu podroben reakci se $100 \% \mathrm{H}_{3} \mathrm{PO}_{4}$ za účelem rozpuštění kostního minerálu a uvolnění oxidu uhličitého z bioapatitu. Zbytek byl filtrován a opláchnut deionizovanou

Tab. 1: Seznam vzorků z lokalit Pohansko-JP a Kostice-ZH a výsledky izotopových analýz. Tab. 1: Sample list from Pohansko-JP and Kostice-ZH sites and results of isotope analyses.

\begin{tabular}{|c|c|c|c|c|c|c|c|c|}
\hline inv. číslo & stáří & vzorek & $\begin{array}{c}\boldsymbol{\delta}^{13} \mathrm{C}_{\mathrm{ap}} \\
{[\% 0]^{1}}\end{array}$ & $\begin{array}{c}\delta^{13} \mathbf{C}_{\text {coll }} \\
{[\% 0]}\end{array}$ & $\begin{array}{c}\boldsymbol{\delta}^{15} \mathbf{N}_{\text {coll }} \\
{[\% 0]}\end{array}$ & $\begin{array}{c}\mathbf{C} \\
{[\%]}\end{array}$ & $\begin{array}{c}\mathbf{N} \\
{[\%]}\end{array}$ & $\mathrm{C} / \mathrm{N}$ \\
\hline P-205665 & 9. stol. AD & $\mathrm{m} 1$ & $-10,63$ & $-17,75$ & 11,87 & - & - & - \\
\hline P-133585 & 9. stol. AD & $\mathrm{m} 1$ & - & $-19,30$ & 7,10 & - & - & - \\
\hline P-133350 & 9. stol. AD & $\mathrm{m} 1$ & - & $-20,50$ & 7,20 & - & - & - \\
\hline P-133974 & 9. stol. AD & $\mathrm{m} 1$ & - & $-20,20$ & 8,20 & - & - & - \\
\hline P-130251 & 9. stol. AD & $\mathrm{m} 1$ & - & $-19,70$ & 6,20 & - & - & - \\
\hline P-132547 & 9. stol. AD & $\mathrm{m} 1$ & - & $-21,80$ & 7,80 & - & - & - \\
\hline P-133132 & 9. stol. AD & $\mathrm{m} 1$ & - & $-19,20$ & 8,40 & - & - & - \\
\hline P-127414 & 9. stol. AD & $\mathrm{m} 1$ & - & $-18,60$ & 10,90 & - & - & - \\
\hline JZP-234 & 9. stol. AD & $\mathrm{m} 1$ & $-15,82$ & $-20,14$ & 8,20 & 43,90 & 15,96 & 3,22 \\
\hline JZP-139a & 9. stol. AD & $\mathrm{m} 1$ & $-12,84$ & $-20,58$ & 9,19 & 44,68 & 16,28 & 3,21 \\
\hline JZP-139b & 9. stol. AD & $\mathrm{m} 1$ & $-10,31$ & $-20,17$ & 6,18 & 38,98 & 14,07 & 3,24 \\
\hline P-204750 & 9. stol. AD & tibia & $-11,73$ & $-20,28$ & 6,98 & - & - & - \\
\hline \multicolumn{9}{|c|}{ Kostice-Zadní hrúd } \\
\hline KZH1874 & 1. pol. 11. stol. AD & $\mathrm{m} 1$ & - & $-19,30$ & 5,90 & - & - & - \\
\hline KZH-H03 & 9.-1. pol. 10. stol. AD & $\mathrm{m} 1$ & $-14,13$ & $-20,91$ & 5,90 & 40,57 & 14,63 & 3,24 \\
\hline KZH-30 & 9.-1. pol. 10. stol. AD & $\mathrm{m} 1$ & $-10,42$ & $-18,44$ & 6,57 & 43,95 & 15,89 & 3,24 \\
\hline KZH-179 & Latén & $\mathrm{m} 1$ & $-13,01$ & $-20,67$ & 6,59 & 40,83 & 14,77 & 3,23 \\
\hline
\end{tabular}



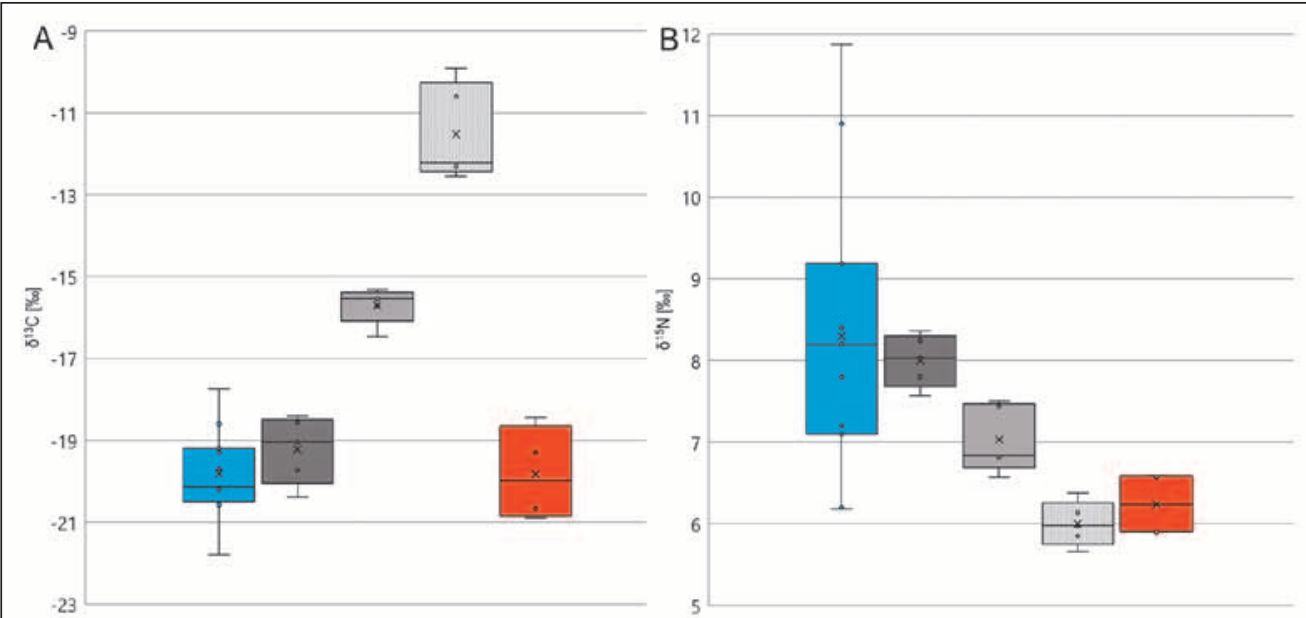

- Pohansko-JP, $\mathrm{m} 1$ घendée, všechny $\mathrm{m} 1$ (průměr) םVendée, všechny m2 (průměr)

- Kostice- $\mathrm{ZH}, \mathrm{m}$

Obr. 3: Srovnání průměrů a rozsahu hodnot $\delta^{13} \mathrm{C}_{\text {coll }}$ a $\delta^{15} \mathrm{~N}_{\text {coll }}$ zubních korunek prvních spodních molárů ( $\mathrm{m} 1 ; \mathrm{n}=11)$ z Pohanska-JP s průměry ze sekvenčních vzorků zubních korunek u m1 (10 vzorků/zub), m2 (12 vzorků/zub) a m3 (6 až 12 vzorků/zub) všech pěti jedinců z experimentální studie Balasse et al. (2001) Fig. 3: Comparison of the mean values and observed ranges of $\delta^{13} \mathrm{C}_{\text {coll }}$ and $\delta^{15} \mathrm{~N}_{\text {coll }}$ of the first lower molars ( $\mathrm{m} 1 ; \mathrm{n}=11)$ from Pohansko-JP with the mean values of the sequential samples from tooth crowns of $\mathrm{m} 1$ (10 samples/tooth), m2 (12 samples/tooth) and m3 (6 to 12 samples/tooth) of all five individuals from experimental study of Balasse et al. (2001).

vodou. Následovalo zahřívání na teplotu $80^{\circ} \mathrm{C}$ po dobu 6 hodin za kyselých podmínek $(\mathrm{pH}=3)$, aby se rozpustil kolagen a došlo k vysrážení nežádoucích huminových látek. Kolagenový roztok se potom filtroval, aby se izoloval čistý kolagen, jenž se následně vysušil. Izotopové složení a koncentrace $\mathrm{C}$ a $\mathrm{N}$ byly změřeny pomocí systému EA-MS Delta V. Poměry ${ }^{13} \mathrm{C} /{ }^{12} \mathrm{C}$ a ${ }^{15} \mathrm{~N} /{ }^{14} \mathrm{~N}$ v kolagenu byly měřeny separátně s použitím hmotnostního spektrometru MAT 251. Použitým standardem pro $\delta^{13} \mathrm{C}$ byl vzorek PDB (Vienna Peedee Belemnite Limestone standard) s chybou $<0,1 \%$ a hodnoty $\delta^{15} \mathrm{~N}$ byly vztaženy $\mathrm{k}$ průměrnému obsahu dusíku v atmosfére s chybou $<0,2 \%$. Vzorky byly analyzovány v laboratořích CAIS (Center for Applied Isotope Studies), University of Georgia.

Kvalita zachování kolagenu byla posouzena třemi kritérii (Vaughan et al. 2013): 1. byly analyzovány pouze vzorky s obsahy kolagenu $>1,0 \mathrm{hm}$. \% odpovídající dobře zachované kosti (např. Brock et al. 2010); 2. do následných analýz byly zahrnuty pouze vzorky s poměrem $\mathrm{C} / \mathrm{N} v$ rozmezí 2,9-3,6 odpovídající dobře zachované kosti (De Niro 1985); 3. vzorky diageneticky změněné s $\mathrm{N}<0,5 \mathrm{hm}$. \% a C $<4,5 \mathrm{hm}$. \% byly $\mathrm{z}$ analýz vyloučeny.

\section{Výsledky}

Výsledky izotopového složení $\delta^{13} \mathrm{C}_{\text {coll }}$ a $\delta^{15} \mathrm{~N}_{\text {coll }}$ dentinu zubních korunek domácího skotu (Bos taurus) ukazuje tabulka 1. Ačkoliv u většiny vzorků ze starších analýz není známá koncentrace $\mathrm{C}$ a $\mathrm{N}(\%)$ ani poměr $\mathrm{C} / \mathrm{N}$, všechny nově analyzované vzorky dentinu dokládají příznivé zachování kolagenu ( $\mathrm{C} / \mathrm{N}=3,21-3,24)$. Příznivé zachování dentinu vykazuje dalších 17 analyzovaných vzorků dentinu ostatních domácích zvírat $\mathrm{z}$ Pohanska (Ivanov, nepubl. data), proto je velmi pravděpodobné, že kolagen
口Vendée, všechny $\mathrm{m} 3$ (prủměr)

se zachoval v odpovídající kvalitě i u dříve analyzovaných vzorků. Data získaná analýzou dentinu ze zubních korunek byla porovnána $s$ průměrným složením zubních korunek molárů z experimentální studie Balasse et al. (2001, s. 239). Toto průměrné složení bylo zjištěno $z$ přepočtených výsledků analýz jednotlivých sekvenčních řezů demineralizovaných molárů. Pro srovnání výsledků z Balasse et al. (2001) s archeozoologickými vzorky bylo využito korekce $\delta^{13} \mathrm{C}_{\text {coll }}+1,4 \%$ (tab. 2, viz e-příloha https://doi.org/10.5817/GVMS2018-1-2-07).

Rozsah hodnot $\delta^{13} \mathrm{C}_{\text {coll }}$ zubního dentinu $\mathrm{m} 1 \mathrm{z}$ Pohanska-JP kolísá v rozpětí $-17,75 \%$ až $-21,8 \%$ o s průměrem $-19,81 \pm 1,03 \%$ o $(\mathrm{n}=11$; obr. $3 \mathrm{~A})$. Hodnota $\delta^{13} \mathrm{C}_{\text {coll }}$ neúplně vyvinuté $\mathrm{m} 1$ (JZP-139a; -20,58 \%o) se nijak neodlišuje od hodnot odpovídajících adultním jedincům $\mathrm{z}$ této lokality, avšak u druhého juvenilního jedince je hodnota $\delta^{13} \mathrm{C}_{\text {coll }}$ výrazně vyšší (obr. $4 \mathrm{~A}$ ) a nespadá do rozpětí hodnot zjištěných u $\mathrm{m} 1$ recentního skotu z referenční studie Balasse et al. (2001). Dentin zubních korunek m1 z Pohanska-JP sice vykazuje vyšší rozpětí hodnot $\delta^{13} \mathrm{C}_{\text {coll }}$ ve srovnání s dentinem recentního skotu z referenční studie Balasse et al. (2001), avšak průměrná hodnota $\delta^{13} \mathrm{C}_{\text {coll }}$ je u skotu z Pohanska výrazně nižší (obr. 3A).

Rozsah hodnot $\delta^{15} \mathrm{~N}_{\text {coll }}$ zubního dentinu $\mathrm{m} 1$ všech vzorků z Pohanska-JP výrazně kolísá v rozpětí $6,2-11,87 \%$ o s průměrem $8,29 \pm 1,71 \%$ o $(n=11$; obr. $3 B)$. Ve srovnání s průměry z přepočtených analýz dentinu recentního skotu je rozsah hodnot $\delta^{15} \mathrm{~N}_{\text {coll }}$ u vzorků z Pohanska-JP výrazně větší a všechny hodnoty zjišstěné Z referenční studie Balasse et al. (2001) spadají do variační šíře $\delta^{15} \mathrm{~N}_{\text {coll }}$ z Pohanska-JP (obr. 3B). Nejvyšší hodnoty $\delta^{15} \mathrm{~N}_{\text {coll }}$ na Pohansku-JP vykazují vzorky dentinu juvenilních jedinců (obr. 4), avšak dentin jednoho dospělého jedince (P-127414) taktéž vykazuje neobvykle vysokou hodnotu $\delta^{15} \mathrm{~N}_{\text {coll }}(10,90 \%$ ).

$\mathrm{Na}$ lokalitě Kostice-ZH hodnoty $\delta^{13} \mathrm{C}_{\text {coll }}$ zubního dentinu $\mathrm{m} 1$ adultních jedinců kolísají v rozpětí -19,30\%o až $-20,91 \%$ s průměrem $-19,83 \pm 1,01 \%$ o $(n=4$; obr. $3 A)$. Průměrná hodnota je nižší ve srovnání s výsledky z experimentální studie Balasse et al. (2001), i když ve svrchní části se variační šíře $\delta^{13} \mathrm{C}_{\text {coll }} \mathrm{u}$ obou porovnaných souborů 
vzájemně překrývají. Ve srovnání s experimentální studií i s Pohanskema-JP je u vzorků m1 z Kostic-ZH výrazně nižší obsah izotopu ${ }^{15} \mathrm{~N}$ (obr. 3B, obr. 5) s průměrem 6,24 $\pm 0,34 \%$ a navíc se žádná hodnota nekryje s variační šírí hodnot zjištěných v referenční studii Balasse et al. (2001).

\section{Diskuze}

Izotopové analýzy vzorků z Pohanska-JP mají nižší hodnoty $\delta^{13} \mathrm{C}_{\text {coll }}$ zubního dentinu ve srovnání s recentním skotem $\mathrm{z}$ experimentálního chovu, který spásal trávu na otevřených loukách s C3 rostlinami (Balasse et al. 2001). Přibližně polovina vzorků spadá do rozpětí hodnot $\delta^{13} \mathrm{C}_{\text {coll }}$ mezi $-21,8 \%$ a $-20,0 \%$ o, které odpovídají výlučně konzumaci C3 rostlin (Katzenberg 2000). U dvou vzorků, jejichž hodnota $\delta^{13} \mathrm{C}_{\text {coll }}$ spadá do rozpětí $-18,6 \%$ až $-17,8 \%$ (tab. 1), nelze ve stravě vyloučit příměs $C 4$ rostlin (Smith, Epstein 1971). Touto příměsí mohlo být proso, které bylo v Evropě využíváno již od neolitu (Hunt et al. 2008) a od pravěku sloužilo jako základní ingredience lidské stravy (Le Huray, Schutkowski 2005; Schmidl et al. 2007; Tafuri et al. 2009). Jelikož průměrné izotopové složení $\delta^{13} \mathrm{C}_{\text {coll }}$ dentinu zubních korunek kojených telat se od jedinců s plně vyvinutými $\mathrm{m} 1$ neliší (obr. 4A), je pravděpodobné, že telata se v prvním roce, $k d y$ dochází k vývoji m1 (Brown et al. 1960; obr. 1A), s postupným přechodem na rostlinnou stravu začala živit stejným spektrem rostlin jako jejich kojící matky, tedy takřka výlučně C3 rostlinami. Porovnáme-li analýzy dentinu apikálních částí zubních korunek recentního skotu (Balasse et al. 2001), jež zachycují izotopové složení dentinu tvořeného výlučně v době kojení (obr. 1C), s analýzami dentinu $\mathrm{m} 1 \mathrm{z}$ Pohanska-JP, lze pozorovat překrývání hodnot $\delta^{13} \mathrm{C}_{\text {coll }}$ (obr. 4B). Jeden adultní jedinec z Pohanska-JP však vykazuje výrazněji sníženou hodnotu (-21,8\%o), která naznačuje, že krávy mohly být na pastvu vyháněny do ekotonů mezi lesem a otevřenějším prostředím, kde může být pokles izotopu ${ }^{13} \mathrm{C}$ výsledkem částečného vlivu tzv. „canopy“ efektu (Lynch et al. 2008; Drucker et al. 2008, 2010). Tento předpoklad je částečně podpořen paleobotanickým záznamem, který ukazuje na prýtomnost lesních porostů s loukami $\mathrm{v}$ těsné blízkosti Pohanska-JP se zvýšeným podílem stromových dřevin (Quercus, Tilia, Betula a Pinus spolu s Poaceae a Asteraceae) a také obecně nižšími hodnotami $\delta^{13} \mathrm{C}_{\text {coll }}$ ve srovnání s recentním skotem $\mathrm{z}$ referenční studie, který spásal trávu na otevřených biotopech (Balasse et al. 2001).

Značné kolísání hodnot $\delta^{15} \mathrm{~N}_{\text {coll }}$ u dentinu zubních korunek by na lokalitě Pohansko-JP mohlo být podmíněno prrítomností jedinců různého ontogenetického stáří (obr. 4A). Z hodnot $\delta^{15} \mathrm{~N}_{\text {coll }}$ zjištěných na Pohansku nejvýrazněji vybočuje dentin ze zubní korunky juvenilního jedince (P-205665; 11,87 \%o), který se v době smrti zcela jistě živil pouze mateřským mlékem. Výživa mateřským mlékem výrazně navyšuje podíl ${ }^{15} \mathrm{~N}$ v organismu (Balasse, 
Tresset 2002; Fuller et al. 2003), tato extrémní hodnota je však i přesto př́liš vysoká. Poněkud přkekvapivým je však u vzorku juvenilního (výlučně kojeného) telete významné obohacení dentinu o izotop ${ }^{13} \mathrm{C}$ ve srovnání s ostatními vzorky z Pohanska-JP. Experimentální studie Balasse et al. (2001) dokládají zvyšování obsahu ${ }^{13} \mathrm{C}$ v dentinu u telat, která z kojení přecházejí na C3 stravu s příměsí $\mathrm{C} 4$ rostlin. Jelikož se tento jedinec živil výhradně mateřským mlékem, vyšší hodnota $\delta^{13} \mathrm{C}_{\text {coll }}$ $\mathrm{v}$ dentinu tohoto jedince naznačuje, že některé dospělé krávy mohli pastevci přikrmovat $\mathrm{C} 4$ rostlinami. Tento předpoklad podporuje přítomnost jednoho dospělého jedince (P-127414) se zvýšeným podílem ${ }^{13} \mathrm{C}$ v dentinu zubní korunky (viz výše). Avšak i u tohoto jedince je obsah ${ }^{15} \mathrm{~N}$ v dentinu zubní korunky neobvykle vysoký a ve srovnání s ostatními vzorky z Pohanska-JP tvoří odlehlou hodnotu (obr. 3B, 4A). Z tohoto důvodu nelze u výše diskutovaných vzorků juvenilního a adultního jedince s odlehlými (extrémními) hodnotami $\delta^{15} \mathrm{~N}_{\text {col }}$ vyloučit částečnou kontaminaci organickými látkami.

Vzorky m1 na lokalitě Kostice-ZH zahrnovaly analýzu dentinu tří dospělých jedinců a jednoho subadultního (obr. 5). Rozsah obecně nízkých hodnot $\delta^{13} \mathrm{C}_{\text {coll }}(-18,44 \%$ o až -20,91\%o) indikuje, že s přechodem na rostlinnou stravu byly v prvním roce života preferenčně konzumovány C3 rostliny (Smith, Epstein 1971). Vzhledem ke zpoždění změny izotopového signálu, který zachycuje novotvořený dentin (Balasse et al. 2001), nelze vyloučit, že mladí jedinci okolo 12 měsíce života již mohli být za účelem porážky přikrmováni stravou s prríměsí $\mathrm{C} 4$ rostlin (především proso). Ukončení vývoje $\mathrm{m} 1$ ve 12 měsíci života jedince však neumožňuje bližší interpretaci. Oproti lokalitě Pohansko-JP jsou však na lokalitě Kostice-ZH překvapivě velmi nízké hodnoty $\delta^{15} \mathrm{~N}_{\text {coll }}$ zubního dentinu. Ty jsou dokonce nižší než hodnoty u zubních korunek m1 a m2 recentního skotu (Balasse et al. 2001), jejichž průměrné izotopové složení je značně ovlivněno kojením a také složením stravy s příměsí luštěnin (obr. 3B, obr. 5). Hodnoty $\delta^{15} \mathrm{~N}_{\text {coll }}$ v kostním kolagenu, a tedy i dentinu, mohou negativně korelovat s průměrnými ročními srážkami (Heaton et al. 1986; Sealy et al. 1987; Vogel et al. 1990). Výzkum divoce žijících severoamerických jelenů běloocasých tuto závislost prokázal pouze u těch jedinců, jejichž strava obsahovala více než 10 \% C4 rostlin (Cormie, Schwarcz 1996). Avšak hodnoty $\delta^{13} \mathrm{C}_{\text {coll }}$ na lokalitě Kostice-ZH neprokazují zvýšenou konzumaci C4 rostlin. Z experimentální studie Ambrose (2000) navíc vyplývá, že závislost $\delta^{15} \mathrm{~N}_{\text {coll }}$ na vlhkostních poměrech je druhově značně proměnlivá. $Z$ uvedeného vyplývá, že nízký obsah ${ }^{15} \mathrm{~N}$ v zubním dentinu nelze přisoudit existenci vlhčí periody. Tento předpoklad dokládá i klimatický vývoj od 2. pol. 10. stol. do konce 11. stol., který je na našem území spojen s mírným poklesem průměrných ročních srážek a relativně stabilním vývojem údolní nivy řeky Dyje, na Pohansku umožňující osídlení i níže položených oblastí (Ložek 2007; Macháček et al. 2007). Jediný vzorek laténského stáří z Kostic-ZH (KZH-179) navíc ukazuje nejvyšší hodnotu $\delta^{15} \mathrm{~N}_{\text {coll }}$ na této lokalitě (6,59\%), i když laténské období je ve znamení zvýšených průměrných ročních srážek (Ložek 2007; Hradecký, Brázdil 2016, obr. 3.2.). Velmi nízký obsah izotopu ${ }^{15} \mathrm{~N}$ v dentinu zubní korunky tura domácího na lokalitě Kostice-ZH může mít více možných vysvětlení: 1 . přikrmování domácího skotu (tj. i dospělých krav) luštěninami, které se vyznačují nízkým obsahem dusíku (Balasse et al. 2001; Balasse, Tresset 2002); 2. dřívější odstavování telat od kojících matek, což je obvyklá praktika využívaná za účelem zvýšení produkce mléka již od neolitu (Balasse, Tresset 2002); 3. kombinace obou faktorů. Podporu této interpretace bude v budoucnu nutné podložit izotopovými daty kostí adultních jedinců skotu, popř́ípadě dentinu $\mathrm{z}$ třetího spodního moláru (m3). Porovnáme-li hodnoty $\delta^{15} \mathrm{~N}_{\text {coll }}$ s lokalitou Pohansko-JP, je patrné, že $\delta^{15} \mathrm{~N}_{\text {coll }} \mathrm{z} \mathrm{m1}$ dospělých jedinců se na Pohansku-JP (po vyloučení jedince s extrémní hodnotou) v průměru pohybuje okolo $7,8 \%$. Tato hodnota je jen nepatrně nižší než je průměr ze sekvenčních vzorků zubních korunek recentních jedinců s obvyklou dobou kojení a odstávkou mezi 7. a 10. měsícem (Balasse et al. 2001; obr. 3B). Většina vzorků z Pohanska-JP ukazuje vyšší podíl ${ }^{15} \mathrm{~N}$ v dentinu zubní korunky $\mathrm{m} 1$ než je hodnota $\delta^{15} \mathrm{~N}_{\text {coll }}$ kostního kolagenu 
tibie adultního jedince (6,98 \%o), u kterého již v důsledku kontinuální remodelace není vliv kojení patrný (Balasse et al. 1999; Richards et al. 2002). Dva vzorky však i zde vykazují výrazně nižší hodnotu $\delta^{15} \mathrm{~N}_{\text {coll }}$ zubního dentinu ml a je pravděpodobné, že se také může jednat o dříve odstavené jedince a/nebo jedince, u kterých nízký signál ${ }^{15} \mathrm{~N}$ odráží přikrmování luštěninami. Bližší interpretace týkající se úvah o možném odstavení by mohlo podat až plánované studium sekvenčních řezů.

\section{Závěr}

Vývoj izotopového složení prvních spodních molárů tura domácího je významně ovlivněn obdobím, kdy dochází ke kojení telat. V průběhu vývoje m1, který je u recentního tura domácího ukončen přibližně ve 13 . měsíci života jedince, dochází ke změně izotopového složení způsobenému s přechodem od kojení na rostlinnou stravu. I když u dospělých jedinců nejsme schopni zjistit, čím byli krmeni těsně před porážkou, je možné sledovat, $v$ jakém prostředí se pásla telata v období postupného odstavování a přechodu na rostlinnou stravu.

Na lokalitách Pohansko-JP i Kostice-ZH lze předpokládat, že se skot živil převážně C3 stravou. Ve srovnání s recentním skotem, který se pásl na otevřených biotopech (Balasse et al. 2001), má skot $\mathrm{z}$ Pohanska-JP v průměru nižší hodnoty $\delta^{13} \mathrm{C}_{\text {coll }} \mathrm{z}$ dentinu zubní korunky, přičemž nejnižší naměřená hodnota ukazuje, že skot z Pohanska-
-JP mohl být na pastvu vyháněn $z$ otevřených luk až do ekotonů v těsné blízkosti lesa. V Kosticích-ZH nejspíše výrazně převažovala pastva na otevřených loukách.

Výrazné kolísání hodnot $\delta^{15} \mathrm{~N}_{\text {coll }}$ na lokalitě Pohansko-JP je zřejmě podmíněno různým ontogenetickým stářím analyzovaných jedinců. Současné výsledky většinou nenaznačují, že by byla telata na Pohansku-JP člověkem předčasně odstavována za účelem zvýšení produkce mléka, avšak u dvou jedinců $\mathrm{z}$ této lokality př̀edčasné odstavení nelze vyloučit. Dentin všech zubních korunek $\mathrm{m} 1$ z lokality Kostice-ZH se vyznačuje výrazně nižšími obsahy ${ }^{15} \mathrm{~N}$ ve srovnání se vzorky z Pohanska-JP. Takto nízké hodnoty $\delta^{15} \mathrm{~N}$ je možné vysvětlit jednak přikrmováním hovězího dobytka stravou s nízkým obsahem dusíku, pravděpodobná je však i možnost dřívějšího odstavování telat za účelem zvýšení produkce mléka. Tento předpoklad bude nutné $\mathrm{v}$ budoucnu ověřit analýzou většího počtu jedinců.

\section{Poděkování}

Děkujeme editorům a recenzentům za kritické pročtení rukopisu a připomínky, které vedly ke zkvalitnění výsledného textu. Práce byla podpořena projektem GAČR 16-15678S Vývoj interakce životního prostředí a subsistenční strategie raně středověké společnosti (Development of interaction of the environment and the subsitent strategy of early medieval society).

\section{Literatura}

Ambrose, S. H. (1990). Preparation and characterization of bone and tooth collagen for isotopic analysis. - Journal of Archaeological Sciences, 17, 4, 431-451. https://doi.org/10.1016/0305-4403(90)90007-R

Ambrose, S. H. (2000). Controlled Diet and Climate Experiments on Nitrogen Isotope Ratios of Rats. - In: Ambrose, S. H., Katzenberg, M. A. (ed.): Biogeochemical Approaches to Paleodietary Analysis, edited by Ambrose and Katzenberg, 243-259, Kluwer Academic / Plenum Publishers New York.

Balasse, M., Bocherens, H., Mariotti, A. (1999). Intra-bone variability of collagen and apatite isotopic composition as evidence of a change of diet. - Journal of Archaeological Science, 26, 593-598. https://doi.org/10.1006/jasc.1998.0376

Balasse, M., Bocherens, H., Mariotti, A., Ambrose, S. H. (2001). Detection of dietary changes by intra-tooth carbon and nitrogen isotopic analysis: An experimental study of dentine collagen of cattle (Bos taurus). - Journal of Archaeological Science, 28, 235-245. https://doi.org/10.1006/jasc.1999.0535

Balasse, M., Tresset, A. (2002). Early weaning of Neolithic domestic cattle (Bercy, France) revealed by intra-tooth Variation in Nitrogen isotope ratios. - Journal of Archaeological Sciences, 29, 853-859. https://doi.org/10.1006/jasc.2001.0725

Balasse, M., Tresset, A., Dobney, K, Ambrose, S. H. (2005). The use of isotope ratios to test for seaweed eating in sheep. - Journal of Zoology, 266, 283-291. https://doi.org/10.1017/S0952836905006916

Beasley, M. J., Brown, W. A. B., Legge, A. J. (1993). Metrical Discrimination between Mandibular First and Second Molars in Domestic Cattle. - International Journal of Osteoarchaeolotfy, 3, 303-314. https://doi.org/10.1002/oa.1390030409

Bocherens, H., Fizet, M., Mariotti, A. (1994). Diet, physiology and ecology of fossil mammals as inferred from stable carbon and nitrogen isotope biogeochemistry: implications for Pleistocene bears. - Paleogeography, Palaeoclimatology, Palaeoecology, 107, 213-225. https://doi.org/10.1016/0031-0182(94)90095-7

Bocherens, H., Fogel, M. L., Tuross, N., Zeder, M. (1995). Trophic structure and climatic information from isotopic signatures in Pleistocene cave fauna of Southern England. - Journal of Archaeological Science, 22, 327-340. https://oi.org/10.1006/ jasc. 1995.0035

Bocherens, H., Billiou, D., Patou-Mathis, M., Bonjean, D., Otte, M., Mariotti, A. (1997). Paleobiological implications of the isotopic signatures $\left({ }^{13} \mathrm{C},{ }^{15} \mathrm{~N}\right)$ of fossil mammal collagen in Scladina Cave (Sclayn, Belgium). - Quaternary Research, 48, 370-380. https://doi.org/10.1006/qres.1997.1927

Bocherens, H., Drucker, D. (2003). Trophic level isotopic enrichment of carbon and nitrogen in bone collagen: case studies from recent and ancient terrestrial ecosystems. - International Journal of Osteoarchaeology, 13, 1-2, 46-53. https://doi. org/10.1002/oa.662 
Brock, F., Higham, T., Bronk Ramsey, C. (2010). Pre-screening techniques for identification of samples suitable for radiocarbon dating of poorly preserved bones. - Journal of Archaeological Science, 37, 855-865. https://doi.org/10.1016/j.jas.2009.11.015

Brown, W. A. B., Christofferson, P. V., Massler, M., Weiss, M. B. (1960). Postnatal tooth development in cattle. - American Journal of Veterinary Research, 21, 7-34.

Cormie, A. B., Schwarcz, H. P. (1996). Effects of climate on deer bone $\delta^{15} \mathrm{~N}$ and $\delta^{13} \mathrm{C}$ : Lack of precipitation offects on $\delta^{15} \mathrm{~N}$ for animals consuminf low amounts of C4 plants. - Geochimica et Cosmochimica Acta, 60, 21, 4161-4166. https://doi.org/10.1016/ S0016-7037(96)00251-7

DeNiro, M. J. (1985). Postmortem preservation and alteration of in vivo bone collagen isotope ratios in relation to paleodietary reconstruction. - Nature, 317(6040), 806-809. https://doi.org/10.1038/317806a0

Dreslerová, G, Hajnalová, M., Macháček, J. (2013). Subsistenční strategie raně středověkých populací v dolním Podyjí. Archeozoologické a archeobotanické vyhodnocení nálezů z výzkumu Kostice - Zadní hrúd (2009-2011). - Archeologické rozhledy, $65,4,825-850$.

Drucker, D. G., Bridault, A., Hobson, K. A., et al. (2008). Can carbon-13 in large herbivores reflect the canopy effect in temperate and boreal ecosystems? Evidence from modern and ancient ungulates. - Palaeogeography, Palaeoclimatology, Palaeoecology, 266, 1-2, 69-82. https://doi.org/10.1016/j.palaeo.2008.03.020

Drucker, D. G., Hobson, K. A., Ouellet, J. P., et al. (2010). Influence of forage preferences and habitat use on ${ }^{13} \mathrm{C}$ and ${ }^{15} \mathrm{~N}$ abundance in wild caribou (Rangifer tarandus caribou) and moose (Alces alces) froma Canada. - Isotopes in Environmental and Health Studies, 46, 1, 107-121.

Fricke, H. C., O'Neil, J. R. (1996). Inter- and intra-tooth variation in the oxygen isotope composition of mammalian tooth enamel: some implications for paleoclimatological and paleobiological research. - Palaeogeography, Palaeoclimatology, Palaeoecology, 126, 91-100. https://doi.org/10.1016/S0031-0182(96)00072-7

Fricke, H. C., Clyde, W. C., O’Neil, J. R. (1998). Intra-tooth variations in $\delta^{18} \mathrm{O}\left(\mathrm{PO}_{4}\right)$ of mammalian tooth enamel as a record of seasonal variations in continental climate variables. - Geochimica et Cosmochimica Acta, 62, 1839-1850. https://doi. org/10.1016/S0016-7037(98)00114-8

Fuller, B. T., Richards, M. P., Mays, S. A. (2003). Stable carbon and nitrogen isotope variations in tooth dentine serial sections from Wharram Percy. - Journal of Archaeological Science, 30, 1673-1684. https://doi.org/10.1016/S0305-4403(03)00073-6

Heaton, J. H. E., Vogel, J. C., Von La Chevallerie, G., Collett, G. ( 1986). Climatic influence on the isotopic composition of bone nitrogen. - Nature, 322, 822-823. https://doi.org/10.1038/322822a0

Hobson, K. A., Sease, J. L. (1998). Stable isotope analyses of tooth annuli reveal temporal dietary records: an example using Steller sea lions. - Marine Mammal Science, 14, 116-129. https://doi.org/10.1111/j.1748-7692.1998.tb00694.x

Hradecký J., Brázdil, R. (2016). Climate in the Past and Present in the Czech Lands in the Central European Context. - In: Pánek, T., Hradecký, J. (eds.): Landscapes and Landforms of the Czech Republic, World Geomorphological Landscapes. http://dx.doi.org/10.1007/978-3-319-27537-6_3

Hunt, H. V., Vander Linden, M., Liu, X., Motuzaite-Matuzeviciute, G., Colledge, S., Jones, M. K. (2008). Millets across Eurasia: chronology and context of early records of the genera Panicum and Setaria from archaeological sites in the Old World. Vegetation History and Archaeobotany, 17, 1, 5-18. https://doi.org/10.1007/s00334-008-0187-1

Katzenberg, A. M. (2000). Stable isotope analysis: a tool for studying past diet, demography and life history. - In: Katzenberg M. A., Saunders S. R. (eds): The Biological Anthropology of the Human Skeleton. New York: John Wiley and sons, 305-327.

Koch, P. L., Fischer, D. C., Dettman, D. (1989). Oxygen isotope variation in the tusks of extinct proboscideans: a measure of season of death and seasonality. - Geology, 17, 515-519. https://doi.org/10.1130/0091-7613(1989)017<0515:OIVITT>2.3.CO;2

Koch, P. L., Heisinger, J., Moss, C., Carlson, R. W., Fogel, M. L., Behrensmeyer, A. K. (1995). Isotopic tracking of change in diet and habitat use in African elephants. - Science, 267, 1340-1343. https://doi.org/10.1126/science.267.5202.1340

Le Huray, J. D., Schutkowski, H. (2005). Diet and social status during the La Tène period in Bohemia: carbon and nitrogen stable isotope analysis of bone collagen from Kutná Hora-Karlov and Radovesice. - Journal of Anthropological Archaeology, 24, 2, 135-147. https://doi.org/10.1016/j.jaa.2004.09.002

Ložek, V. (2007). Zrcadlo minulosti - česká a slovenská krajina v kvartéru. - Dokořán, Praha.

Lynch, A. H., Hamilton, J., Hedges, R. E. M. (2008). Where the wild things are: aurochs and cattle in England. - Antiquity, 82, 318, 1025-1039. https://doi.org/10.1017/S0003598X00097751

Macháček, J. (2007). Early medieval centre in Pohansko near Břeclav/Lundeburg: munitio, emporium or palatium of the rulers of Moravia? - In: Henning J. (ed.): Post-Roman Towns, Trade and Settlement in Europe and Byzantium, Vol. 1: The Heirs of the Roman West. Berlin - New York: Walter de Gruyter GmbH \& Co. KG, 473-498.

Macháček, J., Balcárková, A., Dresler, P., et al. (2013). Archeologický výzkum raně středověkého sídliště Kostice - Zadní hrúd v letech 2009-2011. - Archeologické rozhledy, 65, 4, 735-775.

Macháček, J., Doláková, N., Dresler, P., Havlíček, P., Hladilová, Š., Přichystal, A., Roszková, A., Smolíková, L. (2007). Raně stř̌edověké centrum na Pohansku u Břeclavi a jeho př́rodní prostředí. - Archeologické rozhledy, 59, 278-314.

Makarewicz, C. A., Sealy, J. (2015). Dietary reconstruction, mobility, and the analysis of ancient skeletal tissues: Expanding the prospects of stable isotope research in archaeology. - Journal of Archaeological Science, 56, 146-158. https://doi. org/10.1016/j.jas.2015.02.035

Přichystalová, R. (2011). Problematika pohřbívání na Jižním předhradí velkomoravského hradiska Břeclav-Pohansko. - MS, disertační práce, Masarykova univerzita, Brno.

Reitsema, L. J., Crew, D. E., Polcyn, M. (2010). Preliminary evidence for medieval Polish diet from carbon and nitrogen stable isotopes. - Journal of Archaeological Sciences, 37, 7, 1413-1423. https://doi.org/10.1016/j.jas.2010.01.001

Richards, M. P., Mays, S., Fuller, B. T. (2002). Stable carbon and nitrogen isotope values of bone and teeth reflect weaning age at the Mediaeval Wharram Percy Site, Yorkshire, U.K. - American Journal of Physical Anthropology, 119, 205-210. https:// doi.org/10.1002/ajpa.10124 
Sealy, J. C., Van Der Merwe, N. J., Lee-Thorp, J. A., Lanham, J. L. ( 1987). Nitrogen isotope ecology in southern Africa: Implications for environmental and dietary tracing. - Geochimica et Cosmochimica Acta, 51, 2707-2717. https://doi.org/10.1016/00167037(87)90151-7

Schmidl, A., Jacomet, S., Oeggl, K. (2007). Distribution patterns of cultivated plants in the Eastern Alps (Central Europe) during Iron Age. - Journal of Archaeological Sciences, 34, 2, 243-254. https://doi.org/10.1016/j.jas.2006.05.001

Smith, B. N., Epstein, S. (1971). Two categories of ${ }^{13} \mathrm{C} /{ }^{12} \mathrm{C}$ ratios for higher plants. - Plant Physiology, 47, 3, 380-384. https://doi. org/10.1104/pp.47.3.380

Tafuri, A. M., Craig, E. O., Canci, A. (2009). Stable Isotope Evidence for the Consumption of Millet and Other Plants in Bronze Age Italy. - American Journal of Physical Anthropology, 139, 2, 146-153. https://doi.org/10.1002/ajpa.20955

Vaughan, M., Bonsall, C., Barosiewicz, L., et al. (2013). Variation in the carbon and nitrogen isotopic signatures of pig remains from prehistoric sites in the Near East and Central Europe. - Archeometriai Mühely, 10, 4, 307-312.

Vignatiová, J. (1992). Břeclav-Pohansko II. Slovanské osídlení Jižního předhradí. - Masarykova univerzita, Brno.

Vogel, J. C., Talma, A. S., Hall-Martin, A. J., Viljoen, P. J. ( 1990). Carbon and nitrogen isotopes in elephants. - South African Journal of Science, 86, 147-150. 